\title{
Penggunaan Minyak Sawit dan Pemanasan Bungkil Inti Sawit untuk Manipulasi Ekosistem Rumen terhadap Performans Kambing
}

\author{
The Use of Palm Oil and Heated Palm Kernel Cake to Manipulate Rumen Ecosystem and \\ Goat Performance
}

\author{
T. Akbarillah dan Hidayat \\ Jurusan Peternakan, Fakultas Pertanian, Universitas Bengkulu \\ Jl WR Supratman, Kandang Limun, Bengkulu.38371. Tel/Fax +6-736-21290 \\ Corresponding email: trisakbarillah@yahoo.co.id
}

\begin{abstract}
The research was conducted to evaluate the use palm oil and heated palm kernel cake on goat performance. Twelve local doelings, aging eight months and weighing $14 \mathrm{~kg}$ were used as experimental animal. These goats randomly assigned to four groups of treatments in completely randomized factorial design $2 \times 2$, with 3 replications. First factor was dosing palm oil and second factor was heated palm kernel cake. The ration offered were forage and concentrate in 50:50 ratio. Ration offered were based on nutrient requirements, with Crude Protein (CP) 11.2\% and Total Digestible Nutrients (TDN) 58\%. Variables measured were total intake, digestibility coefficient and average daily gain. Data were analyzed with software of statistical program Systat for Windows, if there were any significant different between treatments, the data were then analyzed with LSD. The result showed that total dry matter $(\mathrm{DM})$, ash, crude protein $(\mathrm{CP})$, ether extract $(\mathrm{EE})$ and nitrogen free extract (NFE) intake and digestibility were no significant different by the use of heated palm kernel cake, dosing palm oil, and their combination ( $\mathrm{P}>0.05)$, except crude fiber $(\mathrm{CF})$ intake was decreased by dosing palm oil. The digestibility coefficient of DM, ash, CP, NFE on use of heated palm kernel cake tended to be higher than unheated palm kernel cake. Average daily gain was no significant different between treatments.
\end{abstract}

Keywords : Palm oil, palm kernel cake, local goat, digestibility, performance

\begin{abstract}
ABSTRAK
Penelitian ini bertujuan mengevaluasi penggunaan minyak sawit dan bungkil inti sawit yang dipanaskan terhadap performan kambing. Kambing lokal digunakan dalam penelitian ini sebanyak 12 ekor umur 8 bulan dengan berat badan $+14 \mathrm{~kg}$. Kambing diacak menjadi 4 kelompok perlakuan berdasarkan Rancangan Acak Faktorial 2X2 dengan 3 ulangan. Faktor pertama ialah penggunaan minyak sawit dan faktor kedua ialah penggunaan bungkil sawit. Pakan diberikan adalah hijauan dan konsentrat dengan perbandingan 50:50. Pakan diberikan berdasarkan kebutuhan PK 11,2\% dan TDN 58\%. Variabel yang diukur adalah total konsumsi, koefisien kecernaan, dan pertambahan berat badan. Data yang diperoleh dianalisis variansi dengan program Systat for Windows, bila berbeda nyata dilanjutkan dengan uji beda nyata terkecil (BNT). Hasil analisis variansi menunjukkan pemanasan bungkil inti sawit berpengaruh tidak nyata $(\mathrm{P}>0,05)$ terhadap konsumsi dan kecernaan bahan kering $(\mathrm{BK})$. Abu, protein kasar (PK), ekstrak eter (EE) dan bahan ekstrak tanpa nitrogen (BETN) sedangkan defaunasi dengan minyak sawit menurunkan konsumsi dan kecernaan serat kasar $(\mathrm{P}<0,05)$. Kombinasi perlakuan menunjukkan pengaruh tidak nyata $(\mathrm{P}>0,05)$. Koefisien cerna $\mathrm{BK}$, abu, PK dan BETN pada perlakuan pemanasan bungkil sawit cenderung lebih tinggi dibanding tanpa pemanasan bungkil sawit. Semua perlakuan berpengaruh tidak nyata terhadap rataan pertambahan berat badan harian.
\end{abstract}

Kata kunci : minyak sawit, bungkil inti sawit, kambing, performans

\section{PENDAHULUAN}

Ketersediaan protein mikroba, terutama dari bakteri dan protozoa, kadang-kadang tidak cukup untuk memenuhi kebutuhan protein hewan agar mencapai produksi tinggi. Hal tersebut akibat potensi sintesis protein mikrobia terbatas yang disebabkan oleh aktivitas protozoa yang memakan bakteri. Hasil dari sintesis protein bakteri, berupa protein bakteri potensial mendukung kebutuhan protein ruminansia untuk dicerna dan diserap pada usus halus. Ketersediaan bakteri dapat berkurang karena aktivitas protozoa memakan bakteri, sedangkan protozoa cenderung hidup bertahan di dalam reticulo rumen.

Untuk meningkatkan suplai protein bakteri diperlukan adanya modifikasi ekosistem mikroba rumen dengan menekan keberadaan protozoa (defaunasi) yang ada di rumen. Oleh 
karena itu produksi protein mikroba pada ruminansia perlu ditingkatkan dengan cara menekan protozoa yang biasanya menyerang bakteri. Untuk menekan kehadiran protozoa dilakukan dengan memberi minyak kelapa sawit, karena minyak goreng juga dapat berfungsi sebagai bahan untuk memanipulasi ekosistem mikrobia rumen (Davis, 2002). Dalam reviewnya disampaikan bahwa penggunaan minyak kacang tanah dapat meningkatkan berat badan sapi secara nyata di Vietnam dan penggunaan minyak goreng $5 \mathrm{ml} / \mathrm{kg}$ berat badan sapi lokal dapat meningkatkan pertambahan berat badan sapi. Penggunaan minyak kacang tanah dengan cara meminumkan sebanyak $6 \mathrm{ml} / \mathrm{kg}$ berat badan sapi yang digemukkan yang diberi pakan rumput, jerami padi, molasses dan dedak padi dapat memperbaiki pertambahan berat badan (Nahn, et al., 2007).

Suplai protein pakan pada ruminansia yang menuju ke usus halus dipengaruhi oleh aktivitas mikroba rumen. Protein pakan kecenderungan terdegradasi oleh mikroba rumen untuk menghasilkan amonia dalam jumlah yang besar. Sebagian amonia tersebut disintesis kembali oleh bakteri menjadi protein bakteri. Protein pakan seharusnya bermanfaat bagi hewan, dicerna menjadi asam amino dan diserap melalui usus halus. Agar protein pakan dapat digunakan lebih efisien, perlu dilindungi dari degradasi mikroba rumen (bypass protein).

Ada beberapa perlakuan untuk melindungi protein pakan seperti pengikatan, penggunaan formaldehid, dan pemanasan. Pemanasan menjadi salah satu perlakuan yang mudah diterapkan. Menurut Widyobroto et al (2000) menyimpulkan dalam penelitiannya bahwa pemanasan pada bungkil kedelai pada suhu $160^{\circ} \mathrm{C}$ selama 30 menit menurunkan potensi degradasi protein (Dt PK) di rumen dan kecernaan protein yang lolos dari rumen $(\mathrm{Kc}$ UDP) masih cukup tinggi.

Bungkil inti sawit merupakan produk sampingan dari industri minyak sawit, tersedia di perkebunan kelapa sawit di Indonesia, populer untuk pakan ternak di tempat feedlot karena mengandung protein cukup tinggi $18 \%$ dan harganya murah. Dengan perlakuan pemanasan, protein bungkil inti sawit diharapkan sebagai bypass protein yang bermanfaat untuk peningkatan pertumbuhan.

Hipotesis penelitian ini ialah penggunaan minyak sawit sebagai agen defaunasi dan bungkil inti sawit yang dipanaskan dapat meningkatkan kecernaan nutrisi dan performan kambing lokal.
Penelitian ini bertujuan untuk mengevaluasi penggunaan minyak sawit dan bungkil inti sawit yang dipanaskan terhadap kecernaan nutrisi dan performan kambing lokal.

\section{MATERI DAN METODE}

Penelitian ini mengevaluasi dua faktor perlakuan yaitu: 1) penggunaan minyak sawit untuk defaunasi dan 2) bungkil inti sawit sebagai protein bypass. Faktor 1 terdiri dari dua perlakuan yaitu : (1) tidak menggunakan minyak sawit dan (2) menggunakan minyak sawit $5 \mathrm{ml} /$ $\mathrm{kg}$ berat badan. Faktor 2 terdiri dari dua perlakuan yaitu : pakan konsentrat dengan bungkil inti sawit tidak dipanaskan (A) dan pakan konsentrat dengan bungkil inti sawit dipanaskan (B) .Jadi ada 4 perlakuan dan 3 ulangan

Penelitian ini menggunakan 12 (dua belas) ekor kambing lokal berumur \pm 8 bulan dengan berat $\pm 14 \mathrm{~kg}$. Dalam penelitian ini digunakan Rancangan Acak Lengkap faktorial (RAL). Dua belas kambing dibagi menjadi empat kombinasi perlakuan, setiap kombinasi perlakuan memiliki tiga ulangan.

Setiap perlakuan diberikan pakan basal rumput lokal 50\% dan pakan konsentrat 50\%. Untuk setiap perlakuan harus mengandung protein kasar (PK) 11,2\% dan total nutrisi yang dapat dicerna (TDN) 66\% (Kearl, 1982). Rumput lapang mengandung $6 \%$ protein kasar (PK) dan total nutrisi yang dapat dicerna (TDN) $58 \%$. Oleh karena itu pakan konsentrat harus mengandung $16,5 \%$ protein kasar (PK) dan $74 \%$ total nutrisi yang dapat dicerna (TDN). Pemberian pakan perlakuan dan formula pakan konsentrat dapat dilihat pada Tabel 1 sedangkan informasi kandungan nutrisi terdapat pada Tabel 2. Perlakuan bypass protein pada bungkil inti sawit dilakukan pemanasan pada suhu $160^{\circ} \mathrm{C}$ selama 30 menit dalam oven. Urea, garam, dan mineral diberikan untuk melengkapi pakan konsentrat agar nutrisi nya seimbang.

\section{Perlakuan Penelitian}

Kambing untuk penelitian adalah kambing yang dikondisikan sehat dan dicegah dari penyakit dengan memberikan obat cacing dan diadaptasikan pada lingkungan kandang dan perlakuan pakan. Kambing yang diberi perlakuan defaunasi diberi minyak kelapa sawit 5 $\mathrm{ml} / \mathrm{kg}$ berat badan melalui mulut dengan menggunakan syring plastik dan diisolasi dari masing-masing kambing tanpa menggunakan perlakuan minyak sawit di kandang isolasi. 
Tabel 1. Pemberian pakan perlakuan dan formula pakan konsentrat (\% BK)

\begin{tabular}{lll}
\hline \multirow{2}{*}{ Bahan pakan } & \multicolumn{2}{c}{ Perlakuan } \\
\cline { 2 - 3 } & $\mathrm{A}$ & $\mathrm{B}$ \\
\hline Rumput lapang (\%) & 50,00 & 50,00 \\
Pakan konsentrat $(\%)$ & 50,00 & 50,00 \\
\hline Formula pakan konsentrat $(\mathrm{kg} / 100 \mathrm{~kg})$ & & \\
-Jagung giling & 15 & 15 \\
-Dedak padi & 30 & 30 \\
-Lumpur minyak sawit & 20 & 20 \\
-Bungkil inti sawit & 25 & - \\
-Bungkil inti sawit yang dipanaskan & - & 25 \\
-NaCl & 3 & 3 \\
-Urea & 2 & 2 \\
-Mineral & 5 & 5 \\
\hline Total & 100,00 & 100,00 \\
\hline
\end{tabular}

Tabel 2. Komposisi kimia bahan pakan

\begin{tabular}{lcc}
\hline Bahan pakan & TDN $(\%)$ & PK $(\%)$ \\
\hline Jagung gilinga & 85,00 & 8,90 \\
Dedak padi a & 74,00 & 13,80 \\
Lumpur minyak sawit $^{\mathrm{b}}$ & 79,00 & 13,25 \\
Bungkil inti sawit & 81,00 & 18,00 \\
Urea $(\mathrm{N}=46 \%)$ PK=Nx6,25 & - & 287,50 \\
$\mathrm{NaCl}$ & - & - \\
Mineral & - & - \\
\hline
\end{tabular}

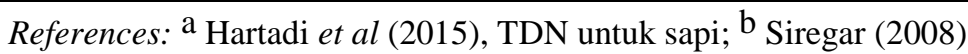

Pakan diberikan $400 \mathrm{~g}$ BK per ekor per hari, terdiri dari $200 \mathrm{~g}$ BK rumput lapang dan 200 g BK pakan konsentrat. Pakan diberikan dua kali sehari pada pukul 08.00 dan 16.00. Air tersedia adlibitum. Setiap ternak ditimbang berat badannya. Kambing ditempatkan di petak kandang individu, yang dilengkapi dengan tempat pakan dan tempat minum dan tempat pemisahan kotoran. Percobaan dilakukan selama 12 minggu dengan periode adaptasi satu minggu. Percobaan kecernaan dilakukan 12 hari. Pakan, sisa pakan, dan feses dikoleksi dan ditimbang setiap hari dan diambil sampel untuk analisis berat kering dan untuk analisis kimianya. Kambing ditimbang setiap dua minggu, sebelum hewan diberi pakan di pagi hari. Variabel yang diamati adalah konsumsi, kecernaan nutrisi seperti bahan kering, bahan organik, protein kasar, ekstrak eter, serat kasar dan bahan ekstrak tanpa Nitrogen dan berat badan awal penelitian dan setelah mencapai 12 minggu.

\section{Analisis data}

Data yang didapat dilakukan analisis ragam (ANOVA) dengan menggunakan paket program perangkat lunak statistik Systat for Windows, apabila terdapat perbedaan dilakukan uji lanjut dengan uji beda nyata terkecil (LSD).

\section{HASIL DAN PEMBAHASAN}

\section{Konsumsi Nutrisi}

Konsumsi nutrisi pada kambing yang diberi pakan konsentrat dengan bungkil inti sawit dipanaskan dan tidak dipanaskan, defaunasi dan non defaunasi dan kombinasinya disajikan pada Tabel 3. Analisis statistik menunjukkan tidak ada pengaruh yang nyata $(\mathrm{P}>0,05)$ terhadap konsumsi bahan kering, bahan anorganik, protein kasar, ekstrak eter, dan bahan ekstrak tanpa nitrogen. Pada perlakuan konentrat dengan bungkil inti sawit tanpa pemanasan cenderung dikonsumsi lebih banyak. Konsentrat dengan bungkil sawit tanpa pemanasan cenderung lebih palatabel daripada bungkil inti sawit yang dipanaskan. Konsumsi pakan dipengaruhi banyak faktor, antara lain aroma, bentuk fisik, kualitas pakan, palatabilitas, kapasitas rumen, yang dikontrol oleh kebutuhan energi (Grovum, 1988 ; NRC, 2007). 
Tabel 3. Rata-rata konsumsi nutrisi kambing yang diberi pakan perlakuan

\begin{tabular}{lcccccc}
\hline \multirow{2}{*}{ Perlakuan } & \multicolumn{6}{c}{ Konsumsi nutrisi (g/ekor/hari) } \\
\cline { 2 - 7 } & $\begin{array}{c}\text { Bahan } \\
\text { kering }\end{array}$ & $\begin{array}{c}\text { Bahan an } \\
\text { organik }\end{array}$ & $\begin{array}{l}\text { Protein } \\
\text { kasar }\end{array}$ & $\begin{array}{c}\text { Serat } \\
\text { kasar }\end{array}$ & $\begin{array}{c}\text { Lemak } \\
\text { kasar }\end{array}$ & BETN \\
\hline Konsentrat & & & & & & \\
A(BS tanpa & & & & & & \\
$\quad$ dipanaskan) & 548,47 & 91,66 & 60,60 & 65,89 & 41,97 & 288,35 \\
B(BS dipanaskan) & 515,19 & 81,65 & 48,41 & 83,10 & 36,18 & 265,85 \\
Defaunasi & & & & & & \\
MS & 508,25 & 88,11 & 59,39 & $60,43^{\mathrm{a}}$ & 44,63 & 255,69 \\
NMS & 555,40 & 85,20 & 49,62 & $88,56^{\mathrm{b}}$ & 33,51 & 298,51 \\
Kombinasi & & & & & & \\
A*MS & 566,01 & 102,93 & 73,12 & 52,93 & 50,17 & 286,86 \\
A*NMS & 530,92 & 80,40 & 48,07 & 78,84 & 33,77 & 289,84 \\
B*MS & 450,49 & 73,29 & 45,67 & 67,93 & 39,09 & 224,51 \\
B*NMS & 579,89 & 90,00 & 51,16 & 98,28 & 33,26 & 307,19 \\
\hline
\end{tabular}

Keterangan : $\quad \mathrm{A}=$ Konsentrat dengan bungkil inti sawit tanpa pemanasan

$\mathrm{B}=$ Konsentrat dengan pemanasan bungkil sawit

$\mathrm{MS}=$ defaunasi dengan minyak sawit

NMS=tidak dilakukan defaunasi/minyak sawit

Superskrip yang berbeda pada kolom yang sama menunjukkan perbedaan yang nyata $(\mathrm{P}<0,05)$

Konsumsi serat kasar secara nyata menurun $(\mathrm{P}<0,05)$, sedangkan konsumsi bahan kering, protein kasar cenderung naik dengan perlakuan defaunasi. Konsumsi bahan kering, bahan anorganik, serat kasar, ekstrak eter dan ekstrak bebas nitrogen berpengaruh tidak nyata $(\mathrm{P}>0,05)$. Hasil penelitian defaunasi pada domba betina diberikan pakan jerami dan konsentrat 70 : 30 tidak memberikan perbedaan yang nyata terhadap konsumsi pakan dan nilai nutrisi (protein dan energi) (Chandramoni et al., 2002). Tidak ada interaksi antara pemanasan bungkil inti sawit dan defaunasi dengan minyak sawit terhadap konsumsi nutrisi. Interaksi bungkil inti sawit tanpa pemanasan dan defaunasi dengan minyak sawit menunjukkan konsumsi nutrisi terbaik.

\section{Kecernaan Nutrisi}

Kecernaan nutrisi disajikan pada Tabel 4. Hasil dari analisis statistik menunjukkan kecernaan BK, PK, EE, dan BETN berpengaruh tidak nyata $(\mathrm{P}>0,05)$ pada konsentrat dengan bungkil inti sawit yang dipanaskan dan tidak dipanaskan. Namun demikian, konsentrat dengan bungkil inti sawit yang dipanaskan sebagai sumber protein bypass cenderung meningkatkan kecernaan nutrisi bahan kering, abu, PK, SK dan BETN. Kecernaan bahan anorganik dan serat kasar pada perlakuan penggunaan bungkil sawit dipanaskan lebih tinggi daripada konsentrat dengan bungkil sawit yang tidak dipanaskan $(\mathrm{P}<0,05)$.

Perlakuan defaunasi tidak meningkatkan kecernaan BK, abu, PK, SK, EE dan BETN (P> 0,05). Seperti hasil penelitian Bhatt et al. (2011), penggunaan minyak kelapa sebagai agen defaunasi menurunkan konsumsi total BK dan kecernaan abu dan PK, namun menaikkan kecernaan EE. Defaunasi tidak meningkatkan asupan dan kecernaan (Trach dan Mai, 2004; Nahn et al., 2007). Penggunaan minyak sawit sebagai agen defaunasi rumen diduga belum memberikan dampak peningkatan populasi bakteri rumen. Minyak sawit diduga seperti minyak kelapa mempunyai daya defaunasi rendah dan kurang dapat menjaga kondisi lingkungan rumen, walaupun populasi protozoa menurun namun tidak dapat meningkatkan jumlah populasi bakteri rumen yang akhirnya berdampak pada rendahnya degradasi bahan kering dan bahan organik (Putra, 2006). Defaunasi pada domba yang diberi pakan dengan proporsi hijauan : kosentrat 30:70 (kualitas pakan yang baik/tinggi) belum memberikan dampak pada peningkatan konsumsi dan nilai nuttrisi/kecernaan pakan (Chandramoni et al., 2002).

Kombinasi perlakuan pemanasan bungkil inti sawit dalam konsentrat dan defaunasi tidak menunjukkan interaksi $(\mathrm{P}>0,05)$. Konsentrat dengan bungkil inti sawit yang dipanaskan dan defaunasi adalah kombinasi perlakuan yang cenderung memiliki kecernaan tertinggi. 
Table 4. Kecernaan nutrisi kambing yang diberi perlakuan

\begin{tabular}{|c|c|c|c|c|c|c|c|}
\hline \multirow{2}{*}{\multicolumn{2}{|c|}{ Perlakuan }} & \multicolumn{6}{|c|}{ Kecernaan $(\%)$} \\
\hline & & $\begin{array}{l}\text { Bahan } \\
\text { kering }\end{array}$ & $\begin{array}{c}\text { Bahan an } \\
\text { organik }\end{array}$ & $\begin{array}{c}\text { Protein } \\
\text { kasar }\end{array}$ & $\begin{array}{l}\text { Serat } \\
\text { kasar }\end{array}$ & $\begin{array}{l}\text { Extract } \\
\text { Eter }\end{array}$ & BETN \\
\hline \multicolumn{8}{|l|}{ Konsentrat } \\
\hline \multicolumn{2}{|c|}{$\mathrm{A}(\mathrm{BS}$ tanpa dipanaskan) } & 80,65 & $80,85^{\mathrm{a}}$ & 83,77 & $62,77^{\mathrm{a}}$ & 91,69 & 80,72 \\
\hline \multicolumn{2}{|c|}{ B (BS dipanaskan) } & 86,67 & $85,19^{\mathrm{b}}$ & 85,83 & $79,00^{\mathrm{b}}$ & 92,44 & 88,70 \\
\hline \multicolumn{8}{|l|}{ Defaunasi } \\
\hline \multicolumn{2}{|l|}{ MS } & 82,53 & 83,38 & 85,50 & 65,67 & 92,15 & 82,52 \\
\hline \multicolumn{2}{|l|}{ NMS } & 84,80 & 82,67 & 84,10 & 76,10 & 91,98 & 86,91 \\
\hline \multicolumn{8}{|l|}{ Kombinasi } \\
\hline \multicolumn{2}{|l|}{$\mathrm{A}^{*} \mathrm{MS}$} & 76,43 & 80,93 & 83,82 & 52,96 & 91,13 & 73,18 \\
\hline \multicolumn{2}{|l|}{ A* NMS } & 84,87 & 80,77 & 83,73 & 72,58 & 92,24 & 88,27 \\
\hline \multicolumn{2}{|l|}{$\mathrm{B}^{*} \mathrm{MS}$} & 88,62 & 85,82 & 87,19 & 78,39 & 93,17 & 91,86 \\
\hline \multicolumn{2}{|l|}{$\mathrm{B} * \mathrm{NMS}$} & 84,72 & 84,57 & 84,46 & 79,61 & 91,71 & 85,55 \\
\hline \multicolumn{8}{|c|}{1 inti sawit tanpa pemanasan } \\
\hline \multicolumn{8}{|c|}{$\mathrm{B}=$ Konsentrat dengan pemanasan bungkil inti sawit } \\
\hline \multicolumn{8}{|c|}{$\mathrm{MS}=$ defaunasi dengan minyak sawit } \\
\hline \multicolumn{8}{|c|}{ NMS=tidak dilakukan defaunasi/minyak sawit } \\
\hline
\end{tabular}

\section{Pertambahan Berat Badan}

Pertambahan berat badan selama penelitian dan kenaikan rata-rata harian disajikan pada Tabel 5. Analisis statistik menunjukkan tidak ada pengaruh perlakuan konsentrat, defaunasi dan kombinasi $(\mathrm{P}>0,05)$. Penggunaan konsentrat dengan bungkil inti sawit tidak dipanaskan dan bungkil inti sawit yang dipanaskan tidak berpengaruh signifikan (P> $0,05)$. Penggunaan bungkil inti sawit yang dipanaskan cenderung mengurangi pertambahan berat badan ternak. Walaupun penggunaan bungkil inti sawit sebagai bypass protein cenderung meningkatkan kecernaan, namun kurang palatabel, sehingga dikonsumsi dalam jumlah tidak banyak. Pertambahan berat badan sangat dipengaruhi oleh konsumsi nutrisinya (Suparman et al, 2016). Kecernaan yang tinggi sebaiknya diikuti konsumsi yang tinggi pula. Defaunasi tidak nyata meningkatkan pertambahan berat badan dalam penelitian ini selaras dengan hasil penelitian Chandramoni et al. (2002). Dalam penelitian ini penggunaan minyak sawit sebagai agen defaunasi cenderung meningkatkan rata-rata kenaikan berat badan harian $0,085 \mathrm{~kg} /$ ekor / hari.

Tabel 5. Pertambahan badan kambing penelitian

\begin{tabular}{lcc}
\hline Treatment & $\begin{array}{c}\text { PBB } \\
(\mathrm{kg} / \text { ekor/12 minggu) }\end{array}$ & $\begin{array}{c}\text { PBB } \\
(\mathrm{kg} / \mathrm{ekor} / \mathrm{hari})\end{array}$ \\
\hline Konsentrat & & \\
A (BS tanpa dipanaskan) & 6,88 & 0,082 \\
B (BS dipanaskan) & 5,08 & 0,061 \\
Defaunasi & & \\
MS & 7,17 & 0,085 \\
NMS & 4,79 & 0,057 \\
Kombinasi & & \\
A*MS & 9,08 & 0,108 \\
A*NMS & 4,67 & 0,056 \\
B*MS & 5,25 & 0,063 \\
B*NMS & 4,92 & 0,059 \\
\hline Keterangan : & A =Konsentrat dengan bungkil inti sawit tanpa pemanasan \\
& $\mathrm{B}=$ Konsentrat dengan pemanasan bungkil inti sawit \\
& MS= defaunasi dengan minyak sawit & \\
& NMS=tidak dilakukan defaunasi/minyak sawit & \\
& Tidak terdapat perbedan yang nyata $(\mathrm{P}<0,05)$ antar perlakuan
\end{tabular}


Kombinasi perlakuan konsentrat dan defaunasi tidak menunjukkan efek interaksi (P> 0,05). Kombinasi perlakuan tersebut cenderung tertinggi diperoleh pada perlakuan kombinasi perlakuan antara bungkil inti sawit tanpa dipanaskan dan dengan dosing minyak kelapa sawit menunjukkan pertambahan berat badan harian cenderung tertinggi $(0,108) \mathrm{kg} / \mathrm{ekor} / \mathrm{hari}$. Menurut Trach dan Mai (2004) dan Nahn et al. (2007) defaunasi tidak dapat meningkatkan konsumsi dan kecernaan pakan. Hasil penelitian dengan perlakuan penggunaan daun waru $0 \%$, $0,24 \%$ dan $0,48 \%$ sebagai agen defaunasi dengan pakan jerami padi dan konsentrat dengan imbangan $35: 65$ dan $30: 70 \%$ pada sapi sumba ongole tidak berdampak pada konsumsi bahan kering, kecernaan bahan organik dan pertambahan berat badan ternak (Bata et al.,2016).

\section{KESIMPULAN}

Penggunaan konsentrat dengan bungkil inti sawit yang dipanaskan sebagai bypass protein cenderung menaikkan kecernaan namun tidak banyak dikonsumsi sehingga pertambahan berat badan cenderung rendah. Penggunaan minyak sawit cenderung menaikkan kecernaan dan pertambahan berat badan. Kombinasi perlakuan tidak ada interaksi namun cenderung paling tinggi pada perlakuan kombinasi penggunaan bungkil inti sawit yang tidak dipanaskan danpenggunaan minyak sawit).

\section{DAFTAR PUSTAKA}

Bata, M., S. Rahayu dan N. Hidayat. 2016. Performance Sapi Sumba Onggole (SO) yang Diberi Jerami Padi Amoniasi dan Konsentrat yang Disuplementasi dengan Tepung Daun Waru (Hibscus tiliceus). $\begin{array}{ll}\text { Agripet. } 16 & \text { (2):106-113. DOI: }\end{array}$ http://doi.org/10.17969/agripet.v16i2. 5334. 106-113

Bhatt, N., M. Soren, M. K. Tripathi, and S.A. Karim. 2011. Effect of Different levels of Coconut oil Suplementation on Performance, digestibility, rumen fermentation and carcass traits of Malpura lambs. Animal Feed Science of Technology 164 (1-2): 29-37.

Chandramoni, C.,M. Tiwari, N. Haque, Murari Lal, S B. Jadhao and M.Y. Khan. 2002.
Energy Balance in Faunated and Defaunated Sheep on a Ration High in Concentrate to Roughage (Good quality) Ratio. DOI: 10 3923/pjn.2002.31-33.

Davis, J. 2002. Utilisation of Low Quality Roughages for Ruminant Feeding, Proceedings: The $3 \mathrm{rd}$ International Seminar on Tropical Animal Production, Gadjah Mada University. Yogyakarta.1516 Oct, 2002.

Grovum, W. L. 1988. Appetite Palatability and Control of Feed Intake . dalam The Rumen Digestive Physiology and Nutrition. D.C. Church. Editor.

Hartadi, H., S. Reksohadiprojo, dan A. D. Tillman. 2015. Tabel Komposisi Pakan untuk Indonesia. Gadjah Mada University Press.

Kearl, L. C, 1982. Nutrient Requirements of Ruminants in Developing Countries, International Feedstuffs Institute, Utah Sate University. Logan Utah.

NRC, 2007. Nutrient Requarements of Small Ruminants. The National Academies Press.Washington, D.C.

Nahn, N. T. H., N. T. Ngu, V.V. Son, T. R. Preston and R. A. Leng. 2007. Effects of Oil drench on growth rate of cattle Estock Rural Development Fattened cattle on grass supplemented with molasses, rice bran or rice traw. Livestock Research for Rural Development. Volume 19, Article \#133. Retrieved September 23, 2020, from

http://www.lrrd.org/lrrd19/9/nhan19133. $\underline{\mathrm{htm}}$

Putra, S. 2006. The Effect Defaunating Agent Suplementation on the In Vitro Dry Matter Degradability and Product Fermentation. Animal Production. 8 (2): 121-130.

Siregar, M. 2008. Konversi Limbah Pertanian sebagai Pakan Ternak Ruminansia 
Fakultas Peternakan Universitas HKBP Monensen. Medan.

Suparman, H. Hafid dan L. O Baa, 2016. Kajian Pertumbuhan dan Produksi Kambing Peranakan Ettawa Jantan yang Diberi Pakan Berbeda. JITRO. 3 (3): 1- 9.

Trach, N. X and T.T. Mai. 2004. Respons of growing beef cattle to a feeding regime combining road side grazing and rice straw feeding supplemented with urea and brewers grains following on oil drench. Livestock Research for Rural Development. Vol. 16, Art. \#53. Retrieved September 23, 2020, from http://www.lrrd.org/lrrd16/7/trach16053. htm

Widyobrototo, B.P., R. Utomo, Kustantinah, dan Windiharti. 2000. Pengaruh pemanasan bungkil kedelai terhadap degradasi protein di rumen dan kecernaan undegraded protein di intestinum. Bull. Anim. Sci. Edisi Khusus. p. 64-69. 